Matthias, $C R$

\title{
CAN WE LEGISLATE FOR PREVENTION AND EARLY INTERVENTION SERVICES FOR CHILDREN? AN ANALYSIS OF ASPECTS OF THE 2002 DRAFT CHILDREN'S BILL
}

Carmel $R$ Matthias is Associate Professor in the School of Social Work at the University of KwaZulu-Natal.

\begin{abstract}
This article provides an explanation and critical analysis of the prevention and early intervention provisions in the South African Law Commission 's 2002 Draft Children's Bill. In addition, the inter-sectoral approach provided for in the Draft Bill and the proposed national policy framework are evaluated. Innovative recommendations that would allow child and family courts to issue early intervention orders are discussed. It is contended in the article that if the prevention and early intervention provisions in the Draft Bill were to be translated into legislation, this could produce significant consequences. It would cause a fundamental shift in balance between proactive and reactive social work services for children in South Africa.
\end{abstract}

\section{INTRODUCTION}

With regard to child abuse and neglect, the main emphasis in the Child Care Act 74/1983 is on dealing with harm once it has occurred in order to prevent it from continuing. The current legislative focus is thus on the tertiary prevention of abuse and on providing for the protection of the child thereafter. Prevention and early intervention do not feature strongly in the Act - they are only briefly referred to in regulation 2(4)(b) (Matthias, 1997:28; Loffell \& Matthias, 1999:13). It is stated in the South African Law Commission's Review of the Child Care Act Issue Paper 13 (1998:24) that:

"A criticism of the present Child Care Act has been that it is narrowly focused, with a heavy emphasis on formal legal interventions in individual situations. This does not meet the needs of the broad mass of South African children".

In an important new initiative with potentially far-reaching consequences, an inter-disciplinary project committee of the South African Law Commission has suggested that express legislative provisions governing prevention and early intervention services for assisting children should be promulgated. Specifically, the project committee proposes that prevention and early intervention provisions should appear in a new Children's Act that would replace the current Child Care Act 74 of 1983. The new proposals are included in the South African Law Commission Draft Children's Bill of December 2002. If implemented, the prevention and early intervention provisions in the Bill could significantly change the current emphasis in services and allocation of resources on behalf of children.

This article offers a critical analysis of the prevention and early intervention provisions as proposed in the 2002 Bill. The purpose of this analysis is to provide conclusions in regard to whether an effective approach has been recommended. Besides the Bill itself, the South African Law Commission has published a body of supporting documentation in which the motivations and reasoning underlying the provisions of the Bill are explained. In this article relevant aspects of the 
supporting documentation are also considered with a view to offering a contextual appreciation of the prevention and early intervention provisions.

\section{DEFINING PREVENTION AND EARLY INTERVENTION SERVICES IN THE 2002 DRAFT CHILDREN'S BILL}

In social work literature prevention services are generally classified into three main levels (Browne 2002:60). Primary prevention services are directed at the general population with the aim of stopping problems before they start. Secondary prevention targets those families where children are thought to be at high risk. Tertiary prevention aims to prevent further maltreatment or abuse of children where it has already occurred. Early intervention services are generally characterised in social work literature as intended to identify potential problems and prevent recurrence of maltreatment and may thus, according to the definition being used, overlap with secondary and tertiary prevention services (Zaal \& Matthias, 2000:123).

In clause 158(1)(b) of the Children's Bill, early intervention services are defined as "...social work services which are - provided to families where there are children identified as being vulnerable to or at risk of harm or removal into alternative care in order to avoid such intervention". Prevention services are defined in clause 158(2)(b) as "...social work services which are - provided to families with children in order to strengthen and build their capacity and self-reliance to address problems that may or are bound to occur in the family environment which, if unchecked, may lead to statutory intervention". A basic criticism of the foundational clause 158 is that it expressly defines prevention and early intervention services as a category of "social work services". Unfortunately, in South Africa there are far too few social workers to serve the needs of the population (McKendrick, 2001:107). In order for prevention and early intervention services to be effective, they need to be provided on a wide scale and implemented by many other service providers besides social workers (see Inter-Ministerial Committee on Young People at Risk, 1996:20) for example, by child-care workers, primary health care workers, community workers and teachers.

The drafters of the Bill did recognise, however, that prevention and early intervention services will require the involvement of a wide range of service providers if they are to be made available in an appropriate manner. A legislative mechanism - referred to in the Bill as a "national policy framework" - has been put forward as the suggested means for providing a range of services to children (including prevention and early intervention services) upon the scale currently required in South Africa. The appropriateness of the national policy framework mechanism and whether it overcomes the shortcomings of clause 158 are discussed in Part 4 of this article below.

\section{PURPOSES TO BE ACHIEVED BY PREVENTION AND EARLY INTERVENTION SERVICES AS FORMULATED IN THE BILL}

As a supplement to clause 158 of the Bill as discussed above, clause 159 provides details of the purposes which prevention and early intervention services must seek to achieve. Some of the purposes outlined in clause 159 are as follows:

- $\quad$ "preserving a child's family structure" (159(1)(a));

- "developing appropriate parenting skills and the capacity of parents and care-givers to safeguard the well-being and best interests of their children" (159(1)(b));

- "preventing the neglect, abuse or inadequate supervision of children and preventing other failures in the family environment to meet children's needs" (159(1)(e)); 
- $\quad$ preventing the recurrence of problems in the family environment that may harm children or adversely affect their development" (159(1)(f));

- "diverting children away from the child and youth care system and the criminal justice system" $(159(1)(\mathrm{g}))$;

- "avoiding the removal of a child from the family environment" (159(1)(h)).

These aims are appropriate in that they are in accordance with the generally accepted purposes of early intervention and prevention services in social work literature.

An additional purpose of prevention and early intervention services which has been described in clause 159(1)(d) is, "...promoting the well-being of children and the realisation of their full potential". It has been argued by some writers that the word "prevention" has negative connotations, whereas the word "promotion," in the context of services for children, has much more positive connotations. An analogy provided by Tomison (n.d.:11) is that "...the prevention of mental disorder in the community is generally described as mental health promotion (i.e. encouraging the development of positive mental health) rather than mental illness prevention..." He therefore argues in favour of the terminology of promotion rather than prevention when referring to services for children and their families. Hargreaves and Hadlow (1995:363) state that the drafters of the 1989 English Children's Act saw prevention as "...an unnecessarily negative term". In addition, they argue that the terms "promotion" and "safeguard" are consistent with the idea of parental responsibility. In their view, social workers, in promoting the welfare of children, should therefore not be focusing on parental shortcomings, but should rather be working in partnership with parents (1995:363). The inclusion of the wording "promoting the well-being of children and the realisation of their full potential" in clause 159(1)(d) of the South African Children's Bill is therefore important and reflects modern international thinking which challenges the notion of merely "prevention". However, since the concept of "prevention" services for children is familiar to South African practitioners, the inclusion of this concept in addition to the "promotion" approach appears to be appropriate at the present time (South African Law Commission Report and Draft Children's Bill, 2002:83).

If promulgated, clauses 158 and 159 as discussed above would clearly provide an important change of emphasis in our child care law. They would encourage much more attention to early intervention and prevention work, as opposed merely to removals of children into alternative care which - as pointed out earlier - is the approach that is salient under the present wording of the Child Care Act. Children's claims to receive proactive and early intervention services in appropriate cases would be considerably strengthened by the proposed new wording. The wording of clauses 158 and 159 would render them useful tools for mobilising the additional resources required in order to provide more extensive prevention and early intervention services than are presently available.

As regards the funding of prevention and early intervention services, clause 160(1) of the Bill provides that "...the Minister may, from money appropriated by Parliament, provide or fund prevention and early intervention services to families, parents, care-givers and children". Clause 160 (2)(a) usefully suggests that children in families which "...lack the means of providing proper shelter, food and other basic necessities of life" must be given priority. With a view to empowering families, clause 160 (2)(b) also requires that, where prevention and early intervention services are to be provided, this must be done with "...the participation of families, parents, caregivers and children in identifying and resolving their problems". It is encouraging to note that, in the Bill's creative conceptualisation of a wide range of new state powers and responsibilities, children and their families are not viewed merely as passive recipients. 


\section{INTER-SECTORAL IMPLEMENTATION OF THE BILL}

It has been widely recognised that in order to provide effective services to children, an intersectoral approach involving different levels and departments of government and also nongovernmental role players is needed (National Committee on Child Abuse and Neglect, 1996; Republic of South Africa: White Paper on Social Welfare, 1997; Tomison, 1998; Department of Social Development's Financing Policy, 1999). Subsequently, Parliament passed the Advisory Board on Social Development Act 3/2001 with the aim of creating a mechanism for inter-sectoral consultations that would assist the Minister of Social Development. An inter-sectoral approach is also strongly promoted in the Bill. The proposed mechanism for achieving inter-sectoral implementation in the Bill is what is described as a "national policy framework". In relation to prevention and early intervention services, clause 161 of the Children's Bill provides that the Minister of Social Development must include in the national policy framework "...a comprehensive national strategy aimed at securing the provision of prevention and early intervention services to families, parents, care-givers and children across the country". Of particular importance in clause 161 is the recognition of the fact that it is necessary "...to build the capacity of government in all spheres to cope with the need for prevention and early intervention services where such capacity is lacking" (clause 161(c)) and "...to develop an efficient and adequate infra-structure for the provision of prevention and early intervention services." (clause 161(d)).

As part of the approach of building the capacity of government in all spheres as referred to in clause 161, clause 162 of the Bill sets out very detailed prevention and early intervention services responsibilities for local government authorities. Involving local government could add significantly to the resources available and facilitate a community or "grassroots" approach (see generally Zaal \& Matthias, 2002). Another important part of the Bill is clause 232. This clause requires that strategies to assist children in especially difficult circumstances must be developed in the national policy framework. These must include measures aimed at combating malnutrition among children. In this regard, the urgent need for a coherent strategy to address childmalnutrition has been highlighted by Mvulane (2003:14) The strategies required by clause 232 must also facilitate the provision of free access to primary and basic health care for impoverished children. In order to involve the private sector, clause $232(1)(\mathrm{a})(\mathrm{xv})$ requires that "...incentives for private sector health care institutions to provide impoverished children access to their services..." must be developed.

The proposed national policy framework is clearly a crucial component of the Children's Bill. As a mechanism for an inter-sectoral approach, it provides for the mandatory development of an integrated plan that would involve a variety of different role players in providing prevention and early intervention services for children and their families. It will be important, in formulating such a plan, that the respective tasks of these role players be clearly delineated. If this is not done, there could be confusion, duplication or an avoidance of responsibilities. If the national policy framework is efficiently developed and implemented, children are likely to benefit from a wide range of legally obligated service providers.

\section{NEW EARLY INTERVENTION POWERS FOR THE CHILD AND FAMILY COURTS}

An important clause in the Children's Bill is clause 164. This clause is worded in such a way as to provide the proposed new child and family courts (which would replace the present children's courts) with a capability to order the provision of early intervention and family preservation services on behalf of children. The first part of clause 164 reads as follows: 
"(1) Before making an order concerning the temporary or permanent removal of a child from that child's family environment, a child and family court may order-

(a) the provincial department of social development, a designated child protection organisation, or any other relevant organ of state to provide early intervention services in respect of the child and the family or parent or care-giver of the child if the court considers the provision of such services appropriate in the circumstances;

(b) the child's family and the child to participate in a recognised family preservation programme."

As can be seen from the wording of the first part of sub-clause 164(1), these powers are expressly intended for proactive use in attempts to render it unnecessary to remove children from dysfunctional families. Currently, the children's courts cannot issue early intervention orders and so this would represent a significant extension of jurisdiction. Clause 164(1) orders must not exceed six months (clause 164(2)). At the end of the period specified by the court, "...a social worker's report setting out progress with early intervention services rendered to the child and the family or the parent or care-giver, must be submitted to the court" (clause 164(3)). The court will then decide whether the child should be removed or whether to order the continuation of early intervention services for a further period (clause 164(4)).

As noted in the previous paragraph, clause 164 allows only for a temporary order lasting up to six months. When deciding upon its final order in a case, a court would utilise clause 59 of the Bill. This clause provides for an extremely wide range of orders which it is recommended courts should be able to choose from, according to the needs of a child in any particular case. A positive aspect is that early intervention services and family preservation programmes again feature expressly in this part of the Bill (see clause 59(1)(g)). Aside from the express mention in sub-clause 59(1) $(\mathrm{g})$, many of the other new powers proposed in other parts of clause 59 could be utilised proactively by courts in continued attempts to avoid a need to remove children into alternative care. Falling into this category are the proposed new child protection orders (clause 59(1)(h)). Some of these child protection orders include:

- "instructing a parent or care-giver undergo professional counselling; or to participate in mediation, a family group conference or other appropriate problem solving forum" (59(1)(h)(iii));

- "instructing a person to undergo a specified skills development, treatment or rehabilitation programme where this is necessary for the protection and well-being of a child" (59(1)(h)(vi);

- "instructing a person who has failed to fulfil an obligation towards a child to appear before the court and to give reasons for the failure" (59(1)(h)(vii);

- "instructing an organ of state assist a child in obtaining access to a public service to which the child is entitled, failing which, to appear through its representative before the court and give reasons for the failure" (59(1)(h)(viii);

- "instructing that a person be removed from the child's home" (59(1)(h)(ix).

The orders proposed in clauses 164 and 59 as referred to above would create new scope for courtmandated early intervention services and other remedies to be offered to families as an alternative to removing children. By empowering courts to order the implementation of early intervention services, clauses 164 and 59 could provide social workers with the backing of the law in cases where they have to deal with uncooperative parents. However, if these new court powers are to be 
effective, money and training will be needed to develop good early intervention programmes throughout the country. Greater numbers of skilled and accredited mediators, accredited family preservation programmes and skilled professionals to conduct family group conferences will be required.

\section{CONCLUSION}

As has been shown, the prevention and early intervention provisions that have been proposed in the Draft Children's Bill are of great potential significance. If implemented, they could produce a fundamental shift in the balance between proactive and reactive social work services for children in South Africa. This would serve as a valuable corrective to the present approach. However, a new emphasis upon prevention and early intervention services should not be achieved at the expense of also providing adequate protection services for children. At a focus group discussion held by the South African Law Commission on 29 April 1999, the participants (who were mainly experienced social workers) supported a balance of resources between preventive and protective services (South African Law Commission Discussion Paper 103, 2001:303).

Although the Draft Children's Bill has the potential to produce a positive impact on the provision of prevention and early intervention services, if such services are to become effective upon the wide scale envisaged, the necessary resources will have to be provided. The new role players, such as local government officials and presiding officers in courts, for example, will require appropriate training if they are to carry out the tasks envisaged for them in the Bill effectively. A major injection of state funding will be required in order to enable the provision of the range and variety of prevention and early intervention services that will have to be made available when the Bill is implemented.

It may be concluded that the prevention and early intervention provisions of the Draft Children's Bill represent an extremely important initiative; but this is an initiative that will require coordinated planning and the necessary finances if it is to be successful. If these provisions appear in legislative form, South Africa will have taken a step forward in implementing article 6(2) of the 1989 United Nations Convention on the Rights of the Child and article 5(2) of the 1990 African Charter on the Rights and Welfare of the Child by promoting the survival and development of children. In addition, some meaningful content will have been given to the part of section 28 (1) (c) of our Constitution which provides a right for children to social services.

\section{REFERENCES}

BROWNE, K. 2002. Child abuse: defining, understanding and intervening. In: WILSON, K. \& JAMES, A. (eds) The child protection handbook. Edinburgh: Bailliere Tindall.

DEPARTMENT OF SOCIAL DEVELOPMENT 1999. Financing Policy: Developmental Social Welfare Services. Government Gazette Vol. 405: General Notice No. 463 of 1999.

HARGREAVES, R.G. \& HADLOW, J. 1995. Preventive intervention as a working concept in child-care practice. British Journal of Social Work, 25:349-365.

INTER-MINISTERIAL COMMITTEE ON YOUNG PEOPLE AT RISK, November 1996. Interim Policy Recommendations.

LOFFELL, J. \& MATTHIAS C.R. 1999. Legislation for child protection. Unpublished research paper presented at a focus group discussion for the South African Law Commission. 
MATTHIAS, C.R. 1997. Removal of children and the right to family life: South African law and practice. Bellville: Community Law Centre, University of Western Cape.

McKENDRICK, B. 2001. The promise of social work: directions for the future. Social Work/Maatskaplike Werk, 37(2):105-111.

MVULANE, Z. 2003. The right to food: If we could eat their words. Children First, 7(47):13-15.

NATIONAL COMMITTEE ON CHILD ABUSE AND NEGLECT 1996. Proposed National Strategy on Child Abuse and Neglect. Pretoria: Department of Welfare.

SOUTH AFRICAN LAW COMMISSION, April 1998. Review of the Child Care Act. First Issue Paper 13 (Project 110).

SOUTH AFRICAN LAW COMMISSION, Dec 2001. Review of the Child Care Act. Discussion Paper 103 (Project 110).

SOUTH AFRICAN LAW COMMISSION, Dec 2002. Review of the Child Care Act. Report and Draft Children's Bill (Project 110).

TOMISON, A. (n.d.). Overcoming structural barriers to the prevention of child abuse and neglect - a discussion paper. National Child Protection Clearing House: Australian Institute of Family Studies.

TOMISON, A. 1998. Preventing child abuse in New South Wales. Australian Institute of Family Studies. Available: http://www.aifs.org.au/external/nch/newslettersspring98.html.

REPUBLIC OF SOUTH AFRICA 1997. WHITE PAPER ON SOCIAL WELFARE, Notice 1108 of 1997. Pretoria: Ministry of Welfare.

ZAAL, F.N. \& MATTHIAS C.R. 2000. The child in need of alternative care. In: DAVEL, C.J. (ed) Introduction to child law in South Africa. Lansdowne: Juta \& Co, Ltd.

ZAAL, F.N. \& MATTHIAS, C.R. 2002. Local government and the provision of child care services: an essential area for legislative reform. The South African Law Journal, 119(1):138154. 